\title{
RESPONSE OF PEANUT CROP CULTIVATED ON A NEWLY RECLAIMED SANDY SOIL TO BIO-INOCULATION, GYPSUM ADDITION AND FOLIAR SPRAY WITH IRON
}

\author{
Metawa M. El-Shouny, Mohamed Abdel Warth and Awatef A. Mahmoud \\ Soils, Water and Environ. Res. Institute, Agric. Res. Center, Giza, Egypt.
}

\section{ABSTRACT:}

A field experiment was carried out on a newly reclaimed sandy soil at South-Tahrir Sector, Al-Behira Governorate, Egypt during the two successive summer seasons of 2008 and 2009, under sprinkler irrigation system. This study was conducted to identify the effect of bio-inoculation by Rhizobium leguminosarum in combination with applied gypsum at the rates of $0,0.5$ and 1.0 ton $\mathrm{fed}^{-1}$ and iron foliar spray at the rates of $0,0.3$ and $0.6 \mathrm{~g}$ $\mathrm{L}^{-1}$ on improving some soil properties as well as peanut pod or seed yield and its contents of oil, protein and nutrients.

The obtained data showed that application of gypsum led to improve some soil properties, i.e., soil bulk density, total porosity, $\mathrm{pH}$ and ECe, where an increased was occurred in soil total porosity. On the contrary, soil bulk density and $\mathrm{pH}$ were decreased, and such favorable effects were achieved at the highest rate of gypsum. The data revealed also that the available contents of NPK as macro and $\mathrm{Fe}, \mathrm{Zn}, \mathrm{Mn}$ and $\mathrm{Cu}$ as micronutrients in soil after peanut harvesting increased as a result of bio-inoculation with rhizobium and gypsum addition, however, the combined treatment of (gypsum at a rate of 1 ton $\mathrm{fed}^{-1}$ with bio-inoculation) gave the best results.

In addition, the applied triple treatment of (bio-inoculation + gypsum + iron foliar spray) significantly increased the number and dry weight of nodules plant ${ }^{-1}$ as well as dry weight of shoot and root of peanut plants at 75 days from sowing. A pronounced increase was achieved in each peanut pod or seed yield and its contents of oil, protein and nutrients (i.e., N, P, K, Fe, $\mathrm{Zn}, \mathrm{Mn}$ and $\mathrm{Cu}$ ). The greatest values for the abovementioned traits were recorded with bio-inoculation. Application of gypsum resulted in a significantly increase for each of the previous peanut parameters, except of potassium content in seed that tended to decrease with increasing the applied rates of gypsum.

Iron foliar spray resulted in a significantly increase for each of the previous peanut parameters in both studied seasons as compared to the control. The greatest values were attained by iron foliar spray at the applied rate of $0.6 \mathrm{~g} \mathrm{~L}^{-1}$, except for $\mathrm{P}, \mathrm{Zn}$ and $\mathrm{Cu}$ contents and uptake that were significantly decreased with increasing the applied rates of Fe as foliar spray. Therefore, under the condition of the studied newly reclaimed sandy soil, the applied gypsum with bio-inoculation plays an effective role for improving soil characters, increasing the available nutrient contents and raising the efficiency of iron foliar spray. This of course positively reflected on peanut yield and improved its seed quality.

Key words: Newly reclaimed sandy soil, rhizobium inoculation, gypsum addition, foliar spray with iron, peanut plants.

Fayoum J. Agric. Res. \& Dev., Vol.25, No.1, January, 2011 


\section{INTRODUCTION:}

Peanut (Arachis hypogaea L.) is considered to be one of the most important edible oil crops in Egypt, which due to its seeds high nutritive value for human and produced cake as well as the green leafy hay for livestock, in addition to the seed oil importance for industrial purposes. Peanut contains about 50\% oil, 25-30\% protein, 20\% carbohydrates and 5\% fiber (Fageria et al., 1997). Peanut is the main summer crop in newly reclaimed sandy soils in Egypt, which are usually poor in plant nutrients and organic matter.

Nitrogen fixation presented by root nodule bacteria is the main source of nitrogen for peanut. Therefore, inoculation of peanut seeds with effective rhizobium has been recommended by many investigators (James et al., 2005; El-Sawy et al., 2006 and Abdalla et al., 2009). Plant growth promoting rhizobium have the ability to enhance the plants growth either directly by phytohormone production, $\mathrm{N}_{2}$-fixation, sidrophores production ....etc. or indirectly, through biological control of pathogens or induction of host defense mechanisms (Glick, 1995). Calcium appears to be essential for the growth of meristems, translocation regulator, activator for some enzymes and functioning of root tips. It is also present as calcium pectate, which is a constituent of the middle lamella of the cell walls. Calcium defacing causes a stunting of the root system and failure of terminal buds of plant (Teuscher et al., 1960 and Russell, 1961).

Utilization of gypsum $\left(\mathrm{CaSO}_{4} \cdot 2 \mathrm{H}_{2} \mathrm{O}\right)$ as a soil amendment refers to improvement of hydrophysical, chemical and biological properties of soil, particularly for agricultural purpose (Morsy et al., 1982). They added that gypsum promoted earlier maturation up to one week and produced the highest yields. Gypsum is the cheapest and best source of $\mathrm{S}$ and $\mathrm{Ca}$ nutrients, which associated with various enzymatic processes of all living cells and biosynthesis (Devakumar, 1995). Addition of gypsum (as a source of $\mathrm{Ca}$ ) believed to be one of the important factors controlling yield and its quality of peanut. In this connection, many investigators found that addition of gypsum increased filling percentage of peanut pods, pod yield/fed and improved yield quality (Taksina, 1994; Ali et al., 1995 and Hussein et al., 2000). Also, Ismail (2005) reported that gypsum application induced a significant increase for each of pods yield and its components as well as shelling and filling percentages of peanut.

Although micronutrients are needed in relatively very small quantities for adequate plant growth and production, their deficiencies induce a great disturbance in different physiological and metabolic processes inside the plant (Nassar et al., 2000). In this concern, iron is essential for plant growth where it occurs in chloroplasts and heme and nonheme proteins and is involved in the mechanisms of photosynthetic, electron transfer as well as in nitrate and sulphate reduction. $\mathrm{Fe}^{2+}$ and $\mathrm{Fe}^{3+}$ ions have also catalytic and structural roles (Morschner, 1998). Yet, Knany et al. (2000) on soybean and Nassar (2007) on peanut stated that oil percentage, seed and straw yields as well as $\mathrm{N}, \mathrm{P}$ and $\mathrm{K}$ contents were significantly increased by foliar addition of iron.

Fayoum J. Agric. Res. \& Dev., Vol.25, No.1, January, 2011 
Therefore, the present study was carried out for evaluating the response of peanut plants grown on a newly reclaimed sandy soil to rhizobium inoculation in combination with gypsum and iron foliar spray applications.

\section{MATERIALS AND METHODS:}

A field experiment was carried out on a newly reclaimed sandy soil at South-Tahrir Sector, Al-Behira Governorate, Egypt during the two successive summer seasons of 2008 and 2009 under sprinkler irrigation system. This study was conducted to identify the effect of Rhizobium leguminosarum as bioinoculation in combination with gypsum at the rates of $0,0.5$ and 1.0 ton $\mathrm{fed}^{-1}$ and iron foliar spray at the rates of $0,0.3$ and $0.6 \mathrm{~g} \mathrm{~L}^{-1}$ added at 30 and 50 days after sowing on improving some soil properties as well as peanut pod or seed yield and its contents of oil, protein and nutrients.

The experimental soil samples $(0-30 \mathrm{~cm}$ depth) were taken before the performance of the experiments. Some physical and chemical analyses of the experimental soil were determined according to Black $\boldsymbol{e t}$ al. (1965) and Page $\boldsymbol{e t}$ al. (1982), and then the obtained data are presented in Table (1). Soil available macronutrients were determined by methods cited by Chapman and Pratt (1961); and soil available $\mathrm{Fe}, \mathrm{Zn}, \mathrm{Mn}$, and $\mathrm{Cu}$ were extracted by the DTPA (Lindsay and Norvell, 1978).

\section{Bacterial inoculants:}

Rhizobium leguminosarum were supplied by the Dpartment of Microbiology, SWERI, ARC, Giza. Strains were characterized by effective ability to infect specific host plants and high efficiency in $\mathrm{N}_{2}$-fixation. Strains were grown on a medium of Vincent (1970). The preparation of these inoculants was carried as vermiculite supplemented with $10 \%$ peat was packed in polyethylene bags $(400 \mathrm{~L})$. Bags were then sealed and sterilized by Gamma irradiation $\left(5.0 \times 10^{6}\right.$ rads). Bacterial culture was injected onto the sterilized vermiculite to satisfy $60 \%$ of water holding capacity of the carrier mixture.

Peanut seeds of the commercial variety Giza 6 were kindly provided by Field Crops Research Institute, Agric. Res. Center, Giza, Egypt. Seeds of peanut were divided into two parts, the first was inoculated with rhizobial inoculants containing the strain and the second was cultivated without inoculation. Seeds of peanut were mixed with suitable amount of Arabic gum $15 \%$ then thoroughly mixed with rhizobial inoculant. The rate of application was $10 \mathrm{~g} / 100 \mathrm{~g}$ seeds (200 $\mathrm{g}$ inoculant/fed). This process was carried out in the field just before seedling. Seeds of peanut were sown in hill $10 \mathrm{~cm}$ apart in ridges on the $18^{\text {th }}$ and $21^{\text {th }}$ of April in the $1^{\text {st }}$ and $2^{\text {nd }}$ seasons, respectively.

Basic application of phosphorus fertilizer, as calcium superphosphate $\left(15.5 \% \mathrm{P}_{2} \mathrm{O}_{5}\right)$ was added during the seed bed preparation at the rate of $30 \mathrm{~kg}$ $\mathrm{P}_{2} \mathrm{O}_{5} /$ feddan. Potassium sulphate $\left(48 \% \mathrm{~K}_{2} \mathrm{O}\right)$ at the rate of $50 \mathrm{~kg} / \mathrm{fed}$ was applied, however, nitrogen fertilizer was applied at a rate of $30 \mathrm{~kg} N / f e d$ as ammonium sulphate $(20.6 \% \mathrm{~N})$. Both $\mathrm{N}$ - and K-fertilizers were applied in two equal doses, i.e., at planting and one month later. The normal cultural practices for peanut were applied as recommended in the sector. Sprinkler irrigation was

Fayoum J. Agric. Res. \& Dev., Vol.25, No.1, January, 2011 
applied as plants needed. Peanut was manually harvested on September $13^{\text {th }}$ and $17^{\text {th }}$ in the first and second seasons, respectively.

Table 1. Some physical, chemical and fertility characteristics of the studied soil.

\begin{tabular}{|c|c|c|c|c|c|c|c|c|c|}
\hline \multirow{2}{*}{\multicolumn{3}{|c|}{ Soil characteristics }} & \multirow{2}{*}{$\frac{\text { Se }}{2008}$} & & \multirow{2}{*}{\multicolumn{3}{|c|}{ Soil characteristics. }} & \multicolumn{2}{|c|}{ season } \\
\hline & & & & 2009 & & & & 2008 & 2009 \\
\hline \multicolumn{3}{|c|}{ Particle size distribution \%: } & \multirow[b]{2}{*}{96.83} & \multirow[b]{2}{*}{93.69} & \multicolumn{3}{|c|}{ CEC (c molc kg ${ }^{-1}$ soil) } & 4.32 & 4.15 \\
\hline \multicolumn{3}{|l|}{$\overline{\text { Sand }}$} & & & $\mathrm{EC} \mathrm{(so}$ & te, $\mathrm{dS} / \mathrm{r}$ & & 0.73 & 0.75 \\
\hline \multicolumn{3}{|l|}{ Silt } & 1.77 & \multirow{2}{*}{$\begin{array}{l}1.53 \\
4.78\end{array}$} & \multicolumn{3}{|c|}{ Soluble cations (mmolc $\left.L^{-1}\right)$ : } & & \\
\hline \multicolumn{3}{|l|}{ Clay } & 4.40 & & & 2.32 & 2.50 \\
\hline \multicolumn{3}{|c|}{ Textural class } & \multicolumn{2}{|c|}{ Sandy } & \multicolumn{3}{|l|}{$\mathrm{Mg}^{++}$} & 1.69 & 1.70 \\
\hline \multicolumn{3}{|c|}{ Bulk density $\left(\mathrm{g} \mathrm{cm}^{-3}\right)$} & 1.55 & 1.53 & \multicolumn{3}{|l|}{$\mathrm{Na}^{+}$} & 3.05 & 3.03 \\
\hline \multicolumn{3}{|c|}{ Total porosity $\%$} & 41.51 & 42.26 & \multirow{2}{*}{\multicolumn{3}{|c|}{$\begin{array}{l}\mathrm{K}^{+} \\
\text {Soluble anions }\left(\text { mmolc } L^{-1}\right) \text { : }\end{array}$}} & 0.25 & 0.27 \\
\hline \multicolumn{3}{|c|}{ Available water \%6.85 } & 6.85 & 6.97 & & & & & \\
\hline \multicolumn{3}{|c|}{ Hydraulic conductivity $\left(\mathrm{cm} \mathrm{h}^{-1}\right)$} & 14.24 & 14.03 & & 0.00 & 0.00 \\
\hline \multicolumn{3}{|l|}{$\mathrm{CaCO}_{3} \%$} & 1.21 & 1.40 & \multicolumn{3}{|l|}{$\mathrm{CO}_{3} \mathrm{HCO}_{3}^{-}$} & 2.60 & 2.63 \\
\hline \multicolumn{3}{|c|}{ Organic matter \% } & 0.29 & 0.35 & $\mathrm{Cl}^{-}$ & & & 2.51 & 2.48 \\
\hline \multicolumn{3}{|c|}{ pH (1:2.5 soil water suspension) } & 7.82 & 7.80 & $\mathrm{SO}_{4}^{--}$ & & & 2.20 & 2.49 \\
\hline \multirow{2}{*}{ Season } & & & \multicolumn{7}{|c|}{ Available nutrients (mg kg-1 soil) } \\
\hline & $\mathrm{N}$ & $\mathrm{P}$ & & $\underline{K}$ & $\mathrm{Fe}$ & $\mathrm{Mn}$ & & & $\mathrm{Cu}$ \\
\hline 2008 & 21 & 3.1 & & 5 & 2.54 & 0.82 & & & 0.35 \\
\hline 2009 & 23 & 3.7 & & 9 & 3.15 & 0.90 & & & 0.40 \\
\hline
\end{tabular}

The experimental design was split-split plot with four replicates, and the plot area was $10.5 \mathrm{~m}^{2}$, and consisting of five rows $(3.5 \mathrm{~m}$ length and $60 \mathrm{~cm}$ between rows). Inoculation with rhizobium was arranged in the main plots. Three rates of gypsum $(0,0.5$ and 1.0 ton/fed) were distributed in the sub plots, however, sub-sub plots were occupied by Fe spraying treatments $(0,0.3$ and 0.6 $\mathrm{g} \mathrm{Fe} / \mathrm{L}$ ) which was done twice at vegetative stage (30 days after sowing) and at pod development period (50 days after sowing) at the rate of $400 \mathrm{~L} / \mathrm{fed}$ in each spray. Five peanut plants were uprooted randomly from each plot after 75 days for determination plant growth, number of root nodules, dry weight of nodules and shoot and root dry weights.

At harvest, the yield and its components were recorded. Ten plants of the middle two rows were taken randomly from each sub-sub plot to record number of pods/plant, pods and seeds weight (g/plant), 100-seed weight (g) and shelling\%. Whole plot was harvested and pods were air dried to calculate pods and seed yield/fed.

Seed contents of $\mathrm{N}, \mathrm{P}, \mathrm{K}, \mathrm{Fe}, \mathrm{Zn}, \mathrm{Mn}$ and $\mathrm{Cu}$ were determined using the methods described by Chapman and Pratt (1961). Protein content \% was calculated by multiplying N\% by 6.25 . Seed oil content $\%$ was determined by using Soxhlet apparatus and petroleum ether as an organic solvent as described by A.O.A.C. (1990).

All data were statistically analyzed according to Snedecor and Cochran (1982). Means of different treatments were compared using the L.S.D test at $5 \%$ probability. Soil samples were collected from the surface layer of each plot $(0-30 \mathrm{~cm})$ to determine some physical and chemical analysis according to Hesse (1977), Loveday (1974) and Black and Hartge (1986).

Fayoum J. Agric. Res. \& Dev., Vol.25, No.1, January, 2011 
RESULTS AND DISCUSSION:

I. Effect of bio-inoculation and gypsum application on some soil properties: a. Soil bulk density and total porosity:

Data in Table (2) showed that there were no differences between uninoculated and inoculated treatments on bulk density and total porosity during the two studied seasons of 2008 and 2009. Data also showed that increasing the rates of gypsum addition, generally decreased the bulk density and increased the total porosity. The decrease in bulk density may be attributed to the effect of both applied gypsum and microbial activity on the redistribution of soil particles which tended to decrease soil bulk density, and consequently the total porosity increasing. The best improved effect was subjected with highest rates of gypsum. These finding are in harmony with those outlined by Abbas $\boldsymbol{e t}$ al. (2004) and Massoud (2006) who found that, the soil bulk density tended to decrease due to increasing gypsum addition.

\section{b. Soil pH:}

The obtained data in Table (2) showed that the $\mathrm{pH}$ values for uninoculated and inoculated treatments were not affected by rhizobium inoculation. Also, data showed that the effect of gypsum addition on $\mathrm{pH}$ values markedly decreased when compared with the treatments without addition. The lowest value of $\mathrm{pH}$ (7.48) was obtained at 1.0 ton gypsum/fed with inoculation. The decline in soil $\mathrm{pH}$ by gypsum application was probably due to the role of applied gypsum and released $\mathrm{SO}_{4}{ }^{2-}$ (Mohamed et al., 1997 and Massoud 2006).

\section{c. Soil electrical conductivity (ECe):}

The application of gypsum with inoculation increased the EC in the studied soil as compared with the control in un-inoculated treatments. The addition of gypsum at the rate of 1.0 ton/fed with inoculation was more affected on ECe than the application $500 \mathrm{~kg} / \mathrm{fed}$. In this respect, Modaihsh et al. (1989) stated that the addition of 0.5 ton $\mathrm{S} / \mathrm{fed}$ significantly decreased the $\mathrm{pH}$ and increased the EC in soil. Similar results were obtained by Nassar (2007).

Table (2): Effect of rhizobium inoculation and gypsum application on some properties of the tested soil at harvesting stage.

\begin{tabular}{|c|c|c|c|c|c|c|c|c|c|}
\hline \multirow{2}{*}{$\begin{array}{c}\text { Bio- } \\
\text { inoculation }\end{array}$} & \multirow{2}{*}{$\begin{array}{c}\text { Gypsum rate } \\
\text { (ton/fed) }\end{array}$} & \multicolumn{2}{|c|}{$\operatorname{ECe}(d S / m)$} & \multicolumn{2}{|c|}{ pH (1:2.5) } & \multicolumn{2}{|c|}{$\begin{array}{c}\text { Bulk density } \\
\left(\mathrm{g} \mathrm{cm}^{-3}\right)\end{array}$} & \multicolumn{2}{|c|}{$\begin{array}{c}\text { Total porosity } \\
\% \\
\end{array}$} \\
\hline & & 2008 & 2009 & 2008 & 2009 & 2008 & 2009 & 2008 & 2009 \\
\hline \multirow{4}{*}{ Un-inoculation } & 0.0 & 0.75 & 0.75 & 7.8 & 7.80 & 1.55 & 1.53 & 41.51 & 42.26 \\
\hline & 0.5 & 0.77 & 0.78 & 7.7 & 7.70 & 1.53 & 1.50 & 42.26 & 43.39 \\
\hline & 1.0 & 0.79 & 0.80 & 7.6 & 7.60 & 1.5 & 1.47 & 43.39 & 44.52 \\
\hline & Mean & 0.77 & 0.77 & --- & --- & 1.53 & 1.50 & 42.38 & 43.39 \\
\hline \multirow{4}{*}{ Inoculation } & 0.0 & 0.77 & 0.76 & 7.78 & 7.78 & 1.55 & 1.53 & 41.51 & 42.26 \\
\hline & 0.5 & 0.81 & 0.80 & 7.68 & 7.68 & 1.52 & 1.49 & 42.64 & 43.77 \\
\hline & 1.0 & 0.83 & 0.82 & 7.6 & 7.60 & 1.49 & 1.46 & 43.77 & 44.90 \\
\hline & Mean & 0.80 & 0.79 & --- & --- & 1.52 & 1.50 & 42.64 & 43.64 \\
\hline
\end{tabular}

Fayoum J. Agric. Res. \& Dev., Vol.25, No.1, January, 2011 
d. Available nutrient contents in soil:

Data in Table (3) showed that available macro and micronutrients content in soil such as $\mathrm{N}, \mathrm{P}, \mathrm{K}$ as well as $\mathrm{Fe}, \mathrm{Zn}, \mathrm{Mn}$ and $\mathrm{Cu}$ increased by rhizobium inoculation after harvesting of peanut plants than un-inoculated treatments, probably due to the root nodules which tended to increase all available nutrients contents in soil. These results are in harmony with those obtained by Mekhemer and Alkahal (2002) and Massoud (2006).

Table (3): Effect of rhizobium inoculation and gypsum application on some soil available nutrient contents at harvesting stage.

\begin{tabular}{|c|c|c|c|c|c|c|c|c|}
\hline $\begin{array}{c}\text { Bio- } \\
\text { inoculation }\end{array}$ & $\begin{array}{c}\text { Gypsum rate } \\
\text { (ton/fed) }\end{array}$ & $\mathbf{N}$ & $\mathbf{P}$ & $\mathbf{K}$ & $\mathbf{F e}$ & Mn & $\mathbf{Z n}$ & $\mathbf{C u}$ \\
\hline \multicolumn{9}{|c|}{ Season of 2008} \\
\hline \multirow{4}{*}{$\begin{array}{c}\text { Un- } \\
\text { inoculation }\end{array}$} & 0.0 & 23 & 3.33 & 48 & 2.65 & 0.85 & 0.73 & 0.35 \\
\hline & 0.5 & 34 & 4.13 & 60 & 2.76 & 0.95 & 0.88 & 0.39 \\
\hline & 1.0 & 38 & 4.86 & 71 & 2.83 & 0.96 & 0.93 & 0.42 \\
\hline & Mean & 32 & 4.10 & 60 & 2.74 & 0.91 & 0.85 & 0.39 \\
\hline \multirow{4}{*}{ Inoculation } & 0.0 & 35 & 4.06 & 53 & 2.79 & 0.85 & 1.03 & 0.38 \\
\hline & 0.5 & 44 & 4.72 & 69 & 2.85 & 0.95 & 1.32 & 0.41 \\
\hline & 1.0 & 49 & 5.03 & 76 & 2.89 & 1.00 & 1.41 & 0.45 \\
\hline & Mean & 42 & 4.60 & 66 & 2.84 & 0.93 & 1.25 & 0.41 \\
\hline \multicolumn{9}{|c|}{ Season of 2009} \\
\hline \multirow{4}{*}{$\begin{array}{c}\text { Un- } \\
\text { inoculation }\end{array}$} & 0.0 & 21 & 3.66 & 45 & 3.16 & 0.92 & 0.70 & 0.43 \\
\hline & 0.5 & 28 & 4.79 & 68 & 3.43 & 0.97 & 0.82 & 0.46 \\
\hline & 1.0 & 31 & 5.06 & 78 & 3.61 & 1.00 & 0.86 & 0.48 \\
\hline & Mean & 27 & 4.50 & 63 & 3.40 & 0.96 & 0.79 & 0.46 \\
\hline \multirow{4}{*}{ Inoculation } & 0.0 & 40 & 4.01 & 61 & 4.05 & 0.90 & 0.90 & 0.51 \\
\hline & 0.5 & 43 & 5.13 & 72 & 4.33 & 0.97 & 0.96 & 0.57 \\
\hline & 1.0 & 50 & 5.65 & 80 & 4.62 & 1.05 & 1.00 & 0.63 \\
\hline & Mean & 44 & 4.93 & 71 & 4.34 & 0.97 & 0.95 & 0.57 \\
\hline
\end{tabular}

Regarding gypsum addition, data showed that available nutrients in soil increased with increasing doses of gypsum addition. The greatest values of available macro and micronutrients were obtained with 1.0 ton gypsum/fed. These increments may be due to that gypsum application caused improvement soil properties, and consequently increasing available nutrients. Similar results were obtained by El-Shahawy (2003), Abbas et al. (2004) and Massoud (2006).

With respect to the combination effect between inoculation and gypsum addition, it can be seen that the high level of gypsum (1.0 ton/fed) with inoculation gave the greatest values of available nutrients content in soil compared with the low rate ( 0.5 ton/fed.) and control. On the other hand, iron foliar spraying has no appreciable effect on the soil properties.

\section{Vegetative growth:}

The number and dry weight of nodules developed on peanut roots and dry weight of shoots and roots taken after 75 days from sowing are presented in

Fayoum J. Agric. Res. \& Dev., Vol.25, No.1, January, 2011 
Table (4). The results revealed that rhizobium inoculation significantly increased the studied plant parameters as compared with the un-inoculated treatments. This increase may be due to the role of rhizobium in increasing plant growth and $\mathrm{N}_{2}$-fixation (Saleh et al., 2007). Also may be due to the production of phytohormones such as auxins, cytokinins, gibberllins and abscic acid by rhizobium. These findings are in agreement with those obtained by Husen (2003) and El-Sawy et al. (2006). The increase in dry weight of shoots and roots may be due to a higher nitrogen accumulation per plant, enhancement of plant vigour and nitrogen fixation (El-Howeity 2008 and El-Howeity et al., 2009).

In this concern, Massoud et al. (2005) indicated that rhizobium inoculation of pea seed and other legumes increased nodulation, also, Abdalla et al. (2009) found that inoculation of peanut with rhizobium led to a significant increase in the nodulation status as compared to the control.

Also, the data showed that addition of gypsum significantly increased the number and dry weight of nodules/plant as well as dry weight of shoots and roots (g) of peanut plants, as shown in Table (5). It can be seen that the highest rate of gypsum $(1.0$ ton/fed) gave the greatest values of these parameters as compared to the low rates and the control. The positive effect of gypsum application could be attributed to improve physical, chemical and biological soil properties, and consequently led to increase the activation in rhizosphere zone. Massoud (2006) and Abdalla et al. (2009) obtained similar results.

Table (4): Number and dry weight of nodules, dry weight of shoots or roots after 75 days of planting as affected by rhizobium inoculation, gypsum and iron foliar spray applications (combined analysis of 2008 and 2009 seasons).

\begin{tabular}{|c|c|c|c|c|c|c|c|c|c|}
\hline \multirow{3}{*}{ i. } & \multirow{3}{*}{ 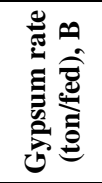 } & \multicolumn{4}{|c|}{ No. of nodules/plant } & \multicolumn{4}{|c|}{ Dry weight of nodules (mg/plant) } \\
\hline & & \multicolumn{8}{|c|}{ Iron foliar spray $(\mathrm{g} / \mathrm{L}), \mathrm{C}$} \\
\hline & & 0.0 & 0.3 & 0.6 & Mean & $\mathbf{0 . 0}$ & 0.3 & 0.6 & Mean \\
\hline \multirow{4}{*}{$\begin{array}{c}\text { Un- } \\
\text { inoculation }\end{array}$} & 0.0 & 23.3 & 25.3 & 26.6 & 25.1 & 150 & 168 & 191 & 169 \\
\hline & 0.5 & 31.6 & 32.0 & 33.3 & 32.9 & 205 & 211 & 228 & 215 \\
\hline & 1.0 & 30.3 & 32.5 & 35.3 & 32.7 & 202 & 228 & 247 & 225 \\
\hline & Mean & 28.4 & 29.9 & 31.7 & 30.2 & 186 & 202 & 222 & 203 \\
\hline \multirow{4}{*}{ Inoculation } & 0.0 & 56.3 & 58.6 & 60.4 & 58.4 & 388 & 392 & 458 & 412 \\
\hline & 0.5 & 61.8 & 65.4 & 68.4 & 65.2 & 390 & 429 & 439 & 419 \\
\hline & 1.0 & 71.5 & 74.4 & 76.6 & 74.1 & 424 & 474 & 484 & 460 \\
\hline & Mean & 63.2 & 66.1 & 68.5 & 56.9 & 400 & 431 & 460 & 430 \\
\hline \multirow{7}{*}{$\begin{array}{l}\text { L.S.D. } \\
\text { at } 0.05\end{array}$} & A & \multicolumn{4}{|c|}{0.23} & \multicolumn{4}{|c|}{20.80} \\
\hline & B & \multicolumn{4}{|c|}{0.27} & \multicolumn{4}{|c|}{12.41} \\
\hline & $\mathrm{C}$ & \multicolumn{4}{|c|}{0.19} & \multicolumn{4}{|c|}{3.45} \\
\hline & $\mathrm{AxB}$ & \multicolumn{4}{|c|}{0.38} & \multicolumn{4}{|c|}{17.58} \\
\hline & $\mathrm{AxC}$ & \multicolumn{4}{|c|}{0.84} & \multicolumn{4}{|c|}{4.87} \\
\hline & $\mathrm{BxC}$ & \multicolumn{4}{|c|}{1.03} & \multicolumn{4}{|c|}{5.96} \\
\hline & $\mathrm{AxBxC}$ & \multicolumn{4}{|c|}{1.46} & \multicolumn{4}{|c|}{8.43} \\
\hline
\end{tabular}

Fayoum J. Agric. Res. \& Dev., Vol.25, No.1, January, 2011 
Metawa M. El-Shouny, et al.

Table (5): Dry weight of shoots or roots after 75 days of planting as affected by rhizobium inoculation, gypsum and iron foliar spray applications (combined analysis of 2008 and 2009 seasons).

\begin{tabular}{|c|c|c|c|c|c|c|c|c|c|}
\hline \multirow{3}{*}{$\begin{array}{c}\text { Bio- } \\
\text { inoculation, } \\
\mathbf{A}\end{array}$} & \multirow{3}{*}{ 急 } & \multicolumn{4}{|c|}{ Dry weight of shoots (g/plant) } & \multicolumn{4}{|c|}{ Dry weight of roots (g/plant) } \\
\hline & & \multicolumn{8}{|c|}{ Iron foliar spray $(\mathrm{g} / \mathrm{L}), \mathrm{C}$} \\
\hline & & 0.0 & 0.3 & 0.6 & Mean & 0.0 & 0.3 & 0.6 & Mean \\
\hline \multirow{4}{*}{$\begin{array}{c}\text { Un- } \\
\text { inoculation }\end{array}$} & 0.0 & 13.67 & 16.19 & 16.81 & 15.56 & 1.36 & 1.54 & 1.64 & 1.51 \\
\hline & 0.5 & 19.75 & 21.65 & 23.05 & 21.48 & 1.75 & 1.79 & 1.82 & 1.78 \\
\hline & 1.0 & 22.26 & 22.81 & 24.20 & 23.09 & 1.94 & 1.98 & 2.03 & 1.98 \\
\hline & Mean & 18.56 & 20.22 & 21.35 & 20.04 & 1.68 & 1.77 & 1.83 & 1.76 \\
\hline \multirow{4}{*}{ Inoculation } & 0.0 & 22.95 & 24.38 & 25.53 & 24.28 & 2.07 & 2.16 & 2.21 & 2.15 \\
\hline & 0.5 & 24.42 & 25.84 & 27.01 & 25.75 & 2.23 & 2.30 & 2.36 & 2.30 \\
\hline & 1.0 & 25.72 & 26.32 & 28.11 & 26.71 & 2.34 & 2.42 & 2.47 & 2.41 \\
\hline & Mean & 24.36 & 25.51 & 26.88 & 25.58 & 2.21 & 2.29 & 2.35 & 2.29 \\
\hline $\begin{array}{l}\text { L.S.D. } \\
\text { at } 0.05\end{array}$ & $\begin{array}{c}\mathrm{A} \\
\mathrm{B} \\
\mathrm{C} \\
\mathrm{A} \times \mathrm{B} \\
\mathrm{A} \times \mathrm{C} \\
\mathrm{B} \times \mathrm{C} \\
\mathrm{AxB} \times \mathrm{C}\end{array}$ & & & & & & & & \\
\hline
\end{tabular}

With respect to the effect of iron foliar spray, the data in Tables (4 and 5) showed that number and weight of nodules/plant as well as dry weight of shoots and roots of peanut plants were increased with increasing iron rates. That means there was a gradual response in the studied parameters of peanut plants due the iron levels increase. The greatest increases of these parameters were obtained by the highest rate of iron as foliar spray.

Concerning the combination effect between bio-inoculation and applied gypsum rates, it can be observed that the highest rate of gypsum (1.0 ton/fed) with bio-inoculation gave the greatest values for all studied parameters of peanut plants after 75 days than the low level $(0.5$ ton/fed $)$ and the control. Also, the interactions effect between the bio-inoculation and iron rates on the previous plant parameters indicated that bio-inoculated treatments were more effective than un-inoculated ones. The highest rate of iron $\left(0.6 \mathrm{~g} \mathrm{~L}^{-1}\right)$ with bioinoculation gave the greatest values for all the studied parameters of peanut plant as compared with the low rate $\left(0.3 \mathrm{~g} \mathrm{Fe} \mathrm{L}^{-1}\right)$ and the control. With regard to the effect of interaction between gypsum and iron levels without bioinoculation, data indicated that the greatest effect of gypsum was recorded with the highest rate of iron $\left(1.0\right.$ ton gypsum fed $\left.{ }^{-1}+0.6 \mathrm{~g} \mathrm{Fe} \mathrm{L}^{-1}\right)$.

Moreover, the best values of different studied plant parameters were obtained at the combined treatment of $\left(1000 \mathrm{~kg}\right.$ gypsum/fed $+0.6 \mathrm{~g} \mathrm{Fe} \mathrm{L}^{-1}$ with bio-inoculation). i.e., 76.6, 484, 28.11 and 2.47 for number of nodules/plant, nodules dry weight (mg/plant), dry weight of shoots (g/plant) and dry weight of roots (g/plant), respectively.

Fayoum J. Agric. Res. \& Dev., Vol.25, No.1, January, 2011 


\section{Yield and its components:}

Data in Tables (6 and 7) showed that Rhizobium leguminosarum inoculation significantly increased pods and seed yields and their components, i.e., No. of pods/plant, seed weight/plant, 100 seed weight (g) and shelling \% as compared with un-inoculated treatments. The positive effect of rhizobium inoculation in yield and its components was achieved due to the activity of root nodules to improve nitrogen fixation by increasing the number of rhizobium, which produced more amounts of bio-fixed nitrogen that led to high peanut yield and its attributes. These results are in agreement with those reported by Osman and Ahmed (2004) and Abdalla et al. (2009) who found that rhizobium inoculation enhanced seeds yield and its components of peanut plants.

Also, the obtained data showed that application of gypsum significantly increased all studied parameters of peanut yield and its components. The greatest effect of gypsum was recorded with the applied highest rate of gypsum (1.0 ton/fed) as compared with low rate of 0.5 ton/fed and the control. These increments may be attributed to the effective role of calcium as an essential macronutrient on plant growth as an activator for some important enzymes, which in turn affected pod and seed weights. These results are in agreement with those obtained by Dahdouh (1999), Hussein et al. (2000) and Ismail (2005). Abou Baker et al. (1994), El-Naggar et al. (1996), Gendy et al. (1996), El-Saadany et al. (2003) and Ismail (2005) studied the effective role of gypsum application on peanut yield and its quality, and their results are in harmony with the findings of the current study.

Table (6): No. of pods/plant, weight of pods/plant and seed weight/plant as affected by rhizobium inoculation, gypsum and iron foliar spray applications (combined analysis of 2008 and 2009 seasons).

\begin{tabular}{|c|c|c|c|c|c|c|c|c|c|c|c|c|c|}
\hline \multirow{3}{*}{ 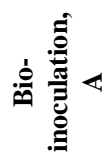 } & \multirow{3}{*}{ 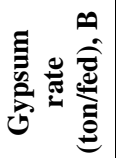 } & \multicolumn{4}{|c|}{ No. of pods/plant } & \multicolumn{4}{|c|}{ Pods weight (g/plant) } & \multicolumn{4}{|c|}{ Seeds weight (g/plant) } \\
\hline & & \multicolumn{12}{|c|}{ Iron foliar spray $(\mathrm{g} / \mathrm{L}), \mathrm{C}$} \\
\hline & & 0.0 & 0.3 & 0.6 & Mean & $\mathbf{0 . 0}$ & 0.3 & 0.6 & Mean & $\mathbf{0 . 0}$ & 0.3 & 0.6 & Mean \\
\hline \multirow{4}{*}{ 主 } & 0.0 & 26.6 & 27.2 & 27.2 & 27.1 & 0 & 33.7 & 35.3 & 33.5 & 24.0 & 27.0 & 28.5 & 26.5 \\
\hline & 0.5 & 28.1 & 28.5 & 28.7 & 28.2 & 31.4 & 42.4 & 44.4 & 45.2 & 30.2 & 33.2 & 34.3 & 32.6 \\
\hline & 1.0 & 28.5 & 29.0 & 28.7 & 28.7 & 38.6 & 47.4 & 45.5 & 45.1 & 32.5 & 35.0 & 34.4 & 34.0 \\
\hline & Mean & 27.7 & 28.2 & 28.3 & 28.0 & 42.5 & 41.2 & 41.7 & 41.3 & 28.9 & 31.7 & 32.4 & 31.0 \\
\hline \multirow{4}{*}{ 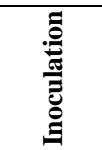 } & 0.0 & 27.3 & 27.8 & 28.2 & 27.8 & 40.8 & 40.5 & 43.4 & 40.2 & 30.3 & 32.0 & 34.7 & 32.3 \\
\hline & 0.5 & 28.9 & 29.5 & 29.6 & 29.3 & 36.8 & 51.3 & 52.6 & 50.5 & 37.4 & 40.0 & 32.0 & 39.7 \\
\hline & 1.0 & 30.3 & 30.6 & 30.7 & 30.6 & 47.5 & 54.4 & 56.3 & $\begin{array}{l}53.8 \\
\end{array}$ & 39.4 & 42.7 & 4306 & 41.9 \\
\hline & Mean & 28.8 & 29.4 & 29.5 & 29.2 & 50.4 & 49.4 & 50.1 & 48.2 & 35.7 & 38.6 & 39.8 & 38.0 \\
\hline $\begin{array}{c}\text { L.S.D. } \\
\text { at } \\
0.05\end{array}$ & $\begin{array}{c}\mathrm{A} \\
\mathrm{B} \\
\mathrm{C} \\
\mathrm{AxB} \\
\mathrm{AxC} \\
\mathrm{BxC} \\
\mathrm{AxB} \times \mathrm{C}\end{array}$ & \multicolumn{4}{|c|}{$\begin{array}{l}0.840 \\
0.048 \\
0.048 \\
0.062 \\
0.068 \\
0.830 \\
0.120\end{array}$} & \multicolumn{4}{|c|}{$\begin{array}{l}0.08 \\
0.16 \\
0.25 \\
0.72 \\
0.36 \\
0.44 \\
0.62\end{array}$} & \multicolumn{4}{|c|}{$\begin{array}{l}0.68 \\
0.25 \\
0.24 \\
0.35 \\
0.33 \\
0.41 \\
0.58\end{array}$} \\
\hline
\end{tabular}

Fayoum J. Agric. Res. \& Dev., Vol.25, No.1, January, 2011 
Table (7): Shelling \%, pods yield/fed, weight of pods/fed and 1000 seed weight/plant as affected by rhizobium inoculation, gypsum and iron foliar spray applications (combined analysis of 2008 and 2009 seasons).

\begin{tabular}{|c|c|c|c|c|c|c|c|c|c|c|c|c|c|c|c|c|c|}
\hline \multirow{3}{*}{ 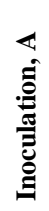 } & \multirow{3}{*}{ 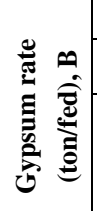 } & \multicolumn{4}{|c|}{ Shelling \% } & \multicolumn{4}{|c|}{ Pod yield (kg/fed) } & \multicolumn{4}{|c|}{ Seeds yield (kg/fed) } & \multicolumn{4}{|c|}{100 seeds weight (g/plant) } \\
\hline & & \multicolumn{16}{|c|}{ Iron foliar spray $(\mathrm{g} / \mathrm{L}), \mathrm{C}$} \\
\hline & & 0.0 & 0.3 & 0.6 & Mean & 0.0 & 0.3 & 0.6 & Mean & 0.0 & 0.3 & 0.6 & Mean & 0.0 & 0.3 & 0.6 & Mean \\
\hline \multirow{4}{*}{ مُ } & 0.0 & 65.2 & 67.0 & 69.1 & 67.1 & 1130 & 1221 & 1255 & 1202 & 726 & 792 & 848 & 789 & 65.5 & 71.0 & 74.6 & 70.3 \\
\hline & 0.5 & 71.9 & 74.0 & 75.0 & 73.6 & 1233 & 1274 & 1334 & 1281 & 841 & 904 & 966 & 904 & 76.8 & 83.1 & 84.5 & 81.5 \\
\hline & 1.0 & 74.0 & 75.1 & 76.3 & 75.2 & 1303 & 1399 & 1500 & 1401 & 921 & 999 & 1081 & 1001 & 81.6 & 86.5 & 87.9 & 85.3 \\
\hline & Mean & 70.4 & 72.0 & 73.5 & 72.0 & 1222 & 1298 & 1363 & 1294 & 829 & 898 & 965 & 898 & 74.0 & 80.2 & 82.3 & 79.0 \\
\hline \multirow{4}{*}{ @ } & 0.0 & 71.1 & 73.2 & 75.0 & 73.1 & 1284 & 1354 & 1415 & 1382 & 910 & 973 & 1059 & 981 & 74.4 & 78.7 & 82.7 & 78.6 \\
\hline & 0.5 & 75.8 & 78.7 & 80.7 & 78.4 & 1407 & 1516 & 1605 & 1510 & 1041 & 1157 & 1234 & 1144 & 87.3 & 93.0 & 94.2 & 91.5 \\
\hline & 1.0 & 80.5 & 82.4 & 84.5 & 82.5 & 1501 & 1631 & 1661 & 1597 & 1160 & 1293 & 1361 & 1271 & 90.7 & 96.0 & 96.2 & 94.3 \\
\hline & Mean & 75.8 & 78.1 & 80.1 & 78.0 & 1397 & 1510 & 1550 & 1496 & 1037 & 1141 & 1218 & 1132 & 84.1 & 89.2 & 91.0 & 88.1 \\
\hline \multirow{7}{*}{ 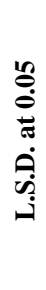 } & A & \multicolumn{4}{|c|}{0.75} & \multicolumn{4}{|c|}{18.97} & \multicolumn{4}{|c|}{5.63} & \multicolumn{4}{|c|}{0.57} \\
\hline & B & \multicolumn{4}{|c|}{0.31} & \multicolumn{4}{|c|}{14.87} & \multicolumn{4}{|c|}{28.39} & \multicolumn{4}{|c|}{0.53} \\
\hline & $\mathrm{C}$ & \multicolumn{4}{|c|}{0.17} & \multicolumn{4}{|c|}{10.82} & \multicolumn{4}{|c|}{9.25} & \multicolumn{4}{|c|}{0.56} \\
\hline & $\mathrm{AxB}$ & \multicolumn{4}{|c|}{0.44} & \multicolumn{4}{|c|}{21.02} & \multicolumn{4}{|c|}{40.22} & \multicolumn{4}{|c|}{0.75} \\
\hline & $\mathrm{AxC}$ & \multicolumn{4}{|c|}{0.24} & \multicolumn{4}{|c|}{15.27} & \multicolumn{4}{|c|}{15.18} & \multicolumn{4}{|c|}{0.78} \\
\hline & $\mathrm{BxC}$ & \multicolumn{4}{|c|}{0.29} & & & 70 & & & & & & & & .96 & \\
\hline & $\mathrm{AxBxC}$ & & & 41 & & & 26 & 45 & & & & 29 & & & & .36 & \\
\hline
\end{tabular}

Data also showed that the effect of iron foliar spray was significantly affected the previous studied peanut parameters. The greatest effect of iron was recorded at the highest rate of $0.6 \mathrm{~g} \mathrm{~L}^{-1}$. These increments may be attributed to the important role of iron for chloroplasts and heme and nonheme proteins. Also, Fe is involved in mechanism of photosynthetic electron transfer as well as in nitrate and sulfate reduction, where the ions of $\mathrm{Fe}^{2+}$ and $\mathrm{Fe}^{3+}$ have catalytic and structural roles. Therefore, Fe promotes the growth of green parts, and consequently produces high yield of pods and seeds (Morschner, 1998 and Nassar et al., 2002). These results are in a good agreement with those reported by Singh (2001), Mehasen and El-Ghazoli (2003) and Nassar (2005).

Concerning the combined effect between bio-inoculation and applied gypsum rates, it could be observed that applied highest rate of gypsum (1.0 ton/fed) in combination with bio-inoculation gave the greatest values of all studied parameters of peanut yield and its attributes as compared with the low rate of 0.5 ton gypsum/fed and the control. Also, the interaction effect between bio-inoculation and applied iron rates on peanut yield and its components indicated that bio-inoculation was more effective than un-inoculated one. Moreover, it could be noticed that the highest iron rate of $0.6 \mathrm{~g} \mathrm{~L}^{-1}$ in combination with bio-inoculation gave the greatest values for all studied parameters of peanut yield and its components as compared with low iron rate $\left(0.3 \mathrm{~g} \mathrm{~L}^{-1}\right)$ and the control.

Fayoum J. Agric. Res. \& Dev., Vol.25, No.1, January, 2011 
Biochemical constituents of peanut seeds:

Data in Tables (8-13) indicated that bio-inoculation treatment of peanut seeds significantly increased N, P, K, Fe, Mn, $\mathrm{Zn}$ and $\mathrm{Cu}$ contents and uptake as well as oil and protein contents either as percent or $\mathrm{kg} / \mathrm{fed}$ of peanut seeds as compared with un-inoculated one. The positive effect of rhizobium inoculation may be due to the increase of nodules number of peanut roots, which increase $\mathrm{N}_{2}$-fixation and its uptake, and consequently increased nitrogen and protein content in peanut seeds. In addition, the positive effect of rhizobium inoculation on the other nutrients of $\mathrm{P}, \mathrm{K}, \mathrm{Fe}, \mathrm{Mn}, \mathrm{Zn}$ and $\mathrm{Cu}$ as well as oil contents in peanut seeds may be due to the pronounced increase in nitrogen bio-fixation, which enhances the vegetative growth of plant, and consequently increased the uptake of these nutrients in peanut seeds. Similar results were obtained by Osman and Ahmed (2004) and Massoud et al. (2005).

Data also showed that either $\mathrm{N}$ or $\mathrm{P}$ content and uptake $(\mathrm{kg} / \mathrm{fed})$ as macronutrients as well as $\mathrm{Fe}, \mathrm{Mn}, \mathrm{Zn}$ and $\mathrm{Cu}$ contents and uptake (g/fed) as micronutrients and both oil and protein contents $(\mathrm{kg} / \mathrm{fed})$ in peanut seeds were significantly increased with increasing the applied gypsum rates. The increments of the nutrient contents as a result of applied gypsum rates may be ascribed to the formation and activation of root nodules, and hence increasing the bio-fixed nitrogen.

Table (8): $\mathbf{N}, P$ and $K$ contents in peanut seeds as affected by rhizobium inoculation, gypsum and iron foliar spray applications (combined analysis of 2008 and 2009 seasons).

\begin{tabular}{|c|c|c|c|c|c|c|c|c|c|c|c|c|c|}
\hline \multirow{3}{*}{ 递泀 } & \multirow{3}{*}{ 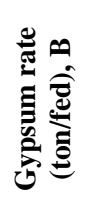 } & \multicolumn{4}{|c|}{$\mathbf{N} \%$} & \multicolumn{4}{|c|}{$\mathbf{P} \%$} & \multicolumn{4}{|c|}{$\mathbf{K} \%$} \\
\hline & & \multicolumn{12}{|c|}{ Iron foliar spray $(\mathrm{g} / \mathrm{L}), \mathrm{C}$} \\
\hline & & 0.0 & 0.3 & 0.6 & Mean & 0.0 & 0.3 & 0.6 & Mean & 0.0 & 0.3 & 0.6 & Mean \\
\hline \multirow{4}{*}{ 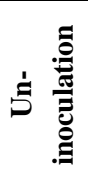 } & 0.0 & 2.18 & 2.54 & 2.72 & 2.48 & 0.15 & 0.24 & 0.22 & 0.20 & 0.95 & 0.98 & 0.93 & 0.95 \\
\hline & 0.5 & 2.60 & 3.00 & 3.18 & 2.92 & 0.32 & 0.30 & 0.28 & 0.30 & 0.89 & 0.82 & 0.80 & 0.83 \\
\hline & 1.0 & 2.82 & 3.16 & 3.38 & 3.12 & 0.36 & 0.35 & 0.30 & 0.33 & 0.70 & 0.73 & 0.68 & 0.70 \\
\hline & Mean & 2.53 & 2.90 & 3.09 & 2.84 & 0.28 & 0.30 & 0.27 & 0.28 & 0.85 & 0.84 & 0.80 & 0.82 \\
\hline \multirow{4}{*}{ 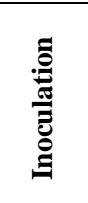 } & 0.0 & 3.50 & 3.89 & 4.17 & 3.85 & 0.33 & 0.30 & 0.27 & 0.30 & 1.18 & 1.25 & 1.26 & 1.23 \\
\hline & 0.5 & 4.00 & 4.50 & 4.58 & 4.36 & 0.37 & 0.34 & 0.32 & 0.34 & 1.03 & 1.04 & 1.06 & 1.04 \\
\hline & 1.0 & 4.27 & 4.63 & 4.80 & 4.56 & 0.42 & 0.36 & 0.34 & 0.37 & 0.90 & 0.93 & 0.90 & 0.91 \\
\hline & Mean & 3.92 & 4.34 & 4.52 & 4.25 & 0.37 & 0.33 & 0.31 & 0.34 & 1.03 & 1.07 & 1.07 & 1.06 \\
\hline
\end{tabular}

Fayoum J. Agric. Res. \& Dev., Vol.25, No.1, January, 2011 
Table (9): N, P and $K$ uptake by peanut seeds as affected by rhizobium inoculation, gypsum and iron foliar spray applications (combined analysis of 2008 and 2009 seasons).

\begin{tabular}{|c|c|c|c|c|c|c|c|c|c|c|c|c|c|}
\hline \multirow{3}{*}{ 然 } & \multirow{3}{*}{ 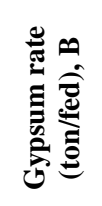 } & \multicolumn{4}{|c|}{$\mathrm{N}$ uptake $\left(\mathrm{kg} \mathrm{fed}^{-1}\right)$} & \multicolumn{4}{|c|}{$P$ uptake $\left(\mathrm{kg} \mathrm{fed}^{-1}\right)$} & \multicolumn{4}{|c|}{ K uptake (kg fed $\left.{ }^{-1}\right)$} \\
\hline & & \multicolumn{12}{|c|}{ Iron foliar spray $(\mathrm{g} / \mathrm{L}), \mathrm{C}$} \\
\hline & & 0.0 & 0.3 & 0.6 & Mean & 0.0 & 0.3 & 0.6 & Mean & $\mathbf{0 . 0}$ & 0.3 & 0.6 & Mean \\
\hline \multirow{4}{*}{ 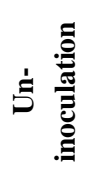 } & 0.0 & 16.40 & 19.87 & 23.32 & 19.86 & 1.08 & 1.90 & 1.86 & 1.61 & 6.91 & 7.82 & 7.91 & 7.54 \\
\hline & 0.5 & 21.95 & 27.39 & 31.20 & 26.84 & 2.69 & 2.71 & 2.70 & 2.70 & 6.72 & 7.41 & 7.72 & 7.28 \\
\hline & 1.0 & 26.24 & 32.16 & 37.07 & 31.82 & 3.31 & 3.49 & 3.24 & 3.34 & 6.44 & 7.29 & 7.13 & 7.05 \\
\hline & Mean & 21.53 & 26.47 & 30.53 & 26.17 & 2.36 & 2.70 & 2.60 & 2.55 & 6.69 & 7.50 & 7.68 & 7.29 \\
\hline \multirow{4}{*}{ 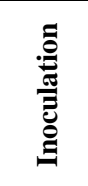 } & 0.0 & 32.39 & 37.55 & 44.47 & 38.14 & 3.00 & 2.91 & 2.85 & 2.92 & 10.73 & 12.16 & 13.34 & 12.07 \\
\hline & 0.5 & 41.53 & 51.60 & 56.39 & 49.84 & 3.85 & 3.93 & 3.94 & 3.91 & 10.72 & 12.03 & 13.08 & 11.94 \\
\hline & 1.0 & 49.30 & 59.34 & 65.60 & 58.08 & 4.87 & 4.78 & 4.62 & 4.75 & 10.44 & 12.02 & 12.24 & 11.57 \\
\hline & Mean & 41.07 & 49.49 & 55.49 & 48.68 & 3.90 & 3.87 & 3.80 & 3.86 & 10.63 & 12.07 & 12.88 & 11.86 \\
\hline \multirow{7}{*}{ 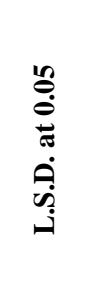 } & A & \multicolumn{4}{|c|}{0.84} & \multicolumn{4}{|c|}{0.06} & \multicolumn{4}{|c|}{0.20} \\
\hline & B & \multicolumn{4}{|c|}{1.27} & \multicolumn{4}{|c|}{0.11} & \multicolumn{4}{|c|}{0.23} \\
\hline & $\mathrm{C}$ & \multicolumn{4}{|c|}{0.64} & \multicolumn{4}{|c|}{0.04} & \multicolumn{4}{|c|}{0.10} \\
\hline & $\mathrm{AxB}$ & \multicolumn{4}{|c|}{1.80} & \multicolumn{4}{|c|}{0.16} & \multicolumn{4}{|c|}{0.32} \\
\hline & $\mathrm{AxC}$ & \multicolumn{4}{|c|}{0.90} & \multicolumn{4}{|c|}{0.05} & \multicolumn{4}{|c|}{0.15} \\
\hline & $\mathrm{BxC}$ & \multicolumn{4}{|c|}{1.10} & \multicolumn{4}{|c|}{0.06} & \multicolumn{4}{|c|}{0.18} \\
\hline & $\mathrm{AxB} \times \mathrm{C}$ & \multicolumn{4}{|c|}{1.56} & \multicolumn{4}{|c|}{0.09} & \multicolumn{4}{|c|}{0.25} \\
\hline
\end{tabular}

The present results coincide with those obtained by Ismail (2005), Othman et al. (2005) and Massoud (2006) who found that gypsum addition to legumes increased N, P, Ca, protein and other nutrients in plants and seeds. On the contrary, a significant reduction in seed $\mathrm{K}$ content was obtained due to application of gypsum. This may be due to the existence of antagonism between $\mathrm{K}$ and $\mathrm{Ca}$ nutrients in soil, such phenomenon is a physiological in nature and occurs during the process of nutrients absorption by roots and further translocation from root to shoots (Shukla and Mukhi, 1979). Moreover, Ismail (2005) found that application of high amount of gypsum lowered the uptake of potassium by plant roots.

Fayoum J. Agric. Res. \& Dev., Vol.25, No.1, January, 2011 
RESPONSE OF PEANUT CROP CULTIVATED ON A NEWLY..... 61

Table 10,11

Fayoum J. Agric. Res. \& Dev., Vol.25, No.1, January, 2011 
Concerning the effect of iron foliar spray on nutrients uptake as well as oil and protein contents of peanut seeds, the obtained data showed that seed contents of $\mathrm{N}, \mathrm{K}, \mathrm{Fe}$ and $\mathrm{Mn}$ and uptake as well as protein and oil contents were significantly increased in both tested seasons when spraying the peanut plants with Fe. The reverse trend was true for seed contents of $\mathrm{P}, \mathrm{Zn}$ and $\mathrm{Cu}$ and their uptake, where significantly decreases were occurred with increasing the applied rate of $\mathrm{Fe}$, this phenomenon may be due to the antagonism between $\mathrm{Fe}$ and these nutrients within plant parts during the process of absorption of nutrients by roots and further translocation from roots to shoots. These findings are in harmony with those reported by Anderson and Parkpin (1988) and Nassar (2005) for either both $\mathrm{Fe}$ and $\mathrm{Zn}$ or $\mathrm{Fe}$ and $\mathrm{Cu}$ antagonisms, respectively.

Table (12): Protein and oil contents \% of peanut seeds as affected by rhizobium inoculation, gypsum and iron foliar spray applications (combined analysis of 2008 and 2009 seasons).

\begin{tabular}{|c|c|c|c|c|c|c|c|c|c|}
\hline \multirow{3}{*}{$\begin{array}{c}\text { Bio- } \\
\text { inoculation, } \\
\text { A }\end{array}$} & \multirow{3}{*}{ 蓄 } & \multicolumn{4}{|c|}{ Protein \% } & \multicolumn{4}{|c|}{ Oil \% } \\
\hline & & \multicolumn{8}{|c|}{ Iron foliar spray $(\mathrm{g} / \mathrm{L}), \mathrm{C}$} \\
\hline & & $\mathbf{0 . 0}$ & 0.3 & 0.6 & Mean & 0.0 & 0.3 & 0.6 & Mean \\
\hline \multirow{4}{*}{$\begin{array}{c}\text { Un- } \\
\text { inoculation }\end{array}$} & 0.0 & 13.62 & 15.87 & 17.00 & 15.50 & 45.13 & 45.65 & 45.77 & 45.51 \\
\hline & 0.5 & 16.25 & 18.75 & 19.87 & 18.25 & 45.82 & 45.97 & 46.02 & 45.93 \\
\hline & 1.0 & 17.62 & 19.75 & 21.12 & 19.50 & 46.16 & 46.57 & 46.83 & 46.52 \\
\hline & Mean & 15.81 & 18.12 & 19.31 & 17.75 & 45.70 & 46.06 & 46.20 & 45.98 \\
\hline \multirow{4}{*}{ Inoculation } & 0.0 & 21.87 & 24.31 & 26.06 & 24.06 & 46.97 & 47.08 & 47.19 & 47.08 \\
\hline & 0.5 & 25.00 & 28.12 & 28.62 & 27.25 & 47.13 & 47.38 & 47.58 & 47.36 \\
\hline & 1.0 & 26.68 & 28.93 & 30.00 & 28.50 & 47.71 & 47.93 & 48.05 & 47.89 \\
\hline & Mean & 24.50 & 27.12 & 28.25 & 26.56 & 47.27 & 47.46 & 47.60 & 47.44 \\
\hline
\end{tabular}

Fayoum J. Agric. Res. \& Dev., Vol.25, No.1, January, 2011 
RESPONSE OF PEANUT CROP CULTIVATED ON A NEWLY.....

Table (13): Protein and oil in $\mathrm{kg} \mathrm{fed}^{-1}$ of peanut seeds as affected by rhizobium inoculation, gypsum and iron foliar spray applications (combined analysis of 2008 and 2009 seasons).

\begin{tabular}{|c|c|c|c|c|c|c|c|c|c|}
\hline \multirow{3}{*}{$\begin{array}{c}\text { Bio-inoculation, } \\
\text { A }\end{array}$} & \multirow{3}{*}{ 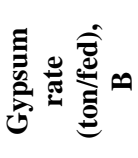 } & \multicolumn{4}{|c|}{ Protein $\left(\mathrm{kg} \mathrm{fed}^{-1}\right)$} & \multicolumn{4}{|c|}{ Oil $\left(\mathrm{kg} \mathrm{fed}^{-1}\right)$} \\
\hline & & \multicolumn{8}{|c|}{ Iron foliar spray $(\mathrm{g} / \mathrm{L}), \mathrm{C}$} \\
\hline & & 0.0 & 0.3 & 0.6 & Mean & 0.0 & 0.3 & 0.6 & Mean \\
\hline \multirow{4}{*}{ Un-inoculation } & 0.0 & 102.50 & 124.19 & 145.75 & 124.14 & 327.6 & 361.5 & 388.1 & 359.1 \\
\hline & 0.5 & 137.18 & 171.18 & 195.00 & 167.78 & 385.3 & 413.6 & 444.6 & 415.2 \\
\hline & 1.0 & 164.00 & 201.00 & 231.68 & 198.89 & 425.1 & 465.2 & 506.2 & 465.5 \\
\hline & Mean & 134.60 & 165.50 & 198.80 & 163.60 & 379.4 & 414.1 & 446.3 & 413.3 \\
\hline \multirow{4}{*}{ Inoculation } & 0.0 & 202.40 & 234.68 & 277.93 & 238.34 & 427.4 & 458.1 & 499.7 & 461.7 \\
\hline & 0.5 & 259.56 & 322.50 & 352.43 & 311.49 & 490.6 & 548.2 & 587.1 & 542.0 \\
\hline & 1.0 & 308.12 & 370.87 & 410.00 & 363.00 & 553.4 & 619.7 & 653.9 & 609.0 \\
\hline & Mean & 256.70 & 309.40 & 346.80 & 304.27 & 490.5 & 542.0 & 580.3 & 537.6 \\
\hline \multirow{7}{*}{$\begin{array}{l}\text { L.S.D. } \\
\text { at } 0.05\end{array}$} & A & \multirow{2}{*}{\multicolumn{4}{|c|}{$\begin{array}{l}11.60 \\
14.23\end{array}$}} & \multicolumn{4}{|c|}{18.91} \\
\hline & B & & & & & \multicolumn{4}{|c|}{19.67} \\
\hline & $\mathrm{C}$ & \multicolumn{4}{|c|}{9.25} & \multicolumn{4}{|c|}{12.00} \\
\hline & $\mathrm{AxB}$ & \multicolumn{4}{|c|}{20.15} & & & & \\
\hline & $\mathrm{AxC}$ & \multicolumn{4}{|c|}{13.05} & \multicolumn{4}{|c|}{16.94} \\
\hline & $\mathrm{BxC}$ & \multicolumn{4}{|c|}{15.99} & \multicolumn{4}{|c|}{20.70} \\
\hline & $\mathrm{AxBxC}$ & \multicolumn{4}{|c|}{22.61} & \multicolumn{4}{|c|}{29.35} \\
\hline
\end{tabular}

Concerning the combined effect between bio-inoculation and applied gypsum rates, the obtained data showed the highest rate of 1.0 ton/fed in combination with bio-inoculation gave the greatest values of $\mathrm{N}, \mathrm{P}, \mathrm{Fe}, \mathrm{Mn}, \mathrm{Zn}$ and $\mathrm{Cu}$ contents and uptake as well as protein and oil contents (kg/fed). However, the greatest values of potassium content and uptake were recorded when plants received the lowest rate of gypsum with bio-inoculation.

Also, studying the combined effect between the bio-inoculation and $\mathrm{Fe}$ foliar spray rates, data observed that the highest rate of iron $(0.6 \mathrm{~g} / \mathrm{L})$ with bioinoculation gave the greatest values of $\mathrm{N}, \mathrm{K}, \mathrm{Fe}$ and $\mathrm{Mn}$ contents and uptake as well as oil and protein contents in peanut seeds. However, bio-inoculation of peanut plants at zero rate of Fe (spraying with tap water) gave the greatest values of $\mathrm{P}, \mathrm{Zn}$ and $\mathrm{Cu}$ contents and uptake.

As for the effect of interaction between applied gypsum and iron foliar spray, the data indicated that the greatest effect was recorded with the highest rate of both gypsum and iron (1.0 ton gypsum/fed $+0.6 \mathrm{~g} \mathrm{Fe} / \mathrm{L})$ for increasing $\mathrm{N}, \mathrm{Fe}$ and Mn contents and uptake as well as oil and protein contents. Meanwhile, the highest rate of gypsum (1.0 ton/fed with $0.3 \mathrm{~g} \mathrm{Fe} / \mathrm{L})$ gave the greatest values of $\mathrm{P}, \mathrm{Zn}$ and $\mathrm{Cu}$ uptake. Also, the highest rate of $\mathrm{Fe}$ without gypsum addition gave the greatest values for potassium content and uptake.

Moreover, the best treatment of interaction between bio-inoculation, gypsum addition and iron foliar spray was obtained at the combined treatment of (1.0 ton gypsum/fed $+0.6 \mathrm{~g} \mathrm{Fe} / \mathrm{L}$ with bio-inoculation) for all nutrient

Fayoum J. Agric. Res. \& Dev., Vol.25, No.1, January, 2011 
contents and uptake as well as oil and protein contents, except of $\mathrm{K}$ content and uptake.

\section{REFERENCES:}

A.O.A.C. (1990). Official Methods of Analysis Association of Official Analytical Chemist. $12^{\text {th }}$ Ed., Washington, D.C., USA.

Abbas, H.H.; E.H.A. Noufal; S.M. Abdel-Aziz and A.S. Saeid (2004). Effect of gypsum application method on improving chemical and physical properties of sodic soils. Workshop on Agricultural Development in The Arab Nation. Obstacles and Solutions, Jan. 20-22, Assiut, Egypt.

Abdalla, A.A.; M.A. El-Howeity and A.H. Desoky (2009). Response of peanut crop cultivated in newly reclaimed soil to inoculation with plant growth- promoting rhizobacteria. Minufia J. Agric. Res., 34(6): 2281-2304.

Abou Bakr, A.A.; M.A. Mahdy; A.O. Osman and S.A. Esmail (1994). Effect of gypsum and phosphorus application on peanut yield and quality. Egypt. J. Appl. Sci., 9(10): 358-371.

Ali, A.A.G.; E.H. Fayed; H.A. Basha and A.M. Hassan (1995). Influence of sowing date and the application of phosphorus and gypsum on yield and yield attributes of peanut. Zagazig J. Agric. Res., 22(I): 49-68.

Anderson, W.B. and P. Parkpian (1988). Effect of soil applied iron by-product and micronutrients concentrations in sorghum cultivars. J. Plant Nut., 11: 1333.

Black, C.A.; D.D. Evans; L.E. Ensminger; J.L. White and F.E. Clark (1965). Methods of Soil Analysis. Amer. Soc. Agron. Inc., Pub., Madison, Wisc., USA.

Black, G.R. and K.H. Hartge (1986). Bulk density. In: Klute, A. (Ed.) methods of Soil Analysis. Part. I: Physical and Mineralogical Methods, $2^{\text {nd }}$ ed. Agron. Manoger. ASA-SSA, Madison, WI, 363-375 pp.

Chapman, D.H. and P.F. Pratt (1961). Methods of Analysis for Soils, Plant and Water. California Univ., Division of Agric. Soil.

Dahdouh, S.M.A.; A.A. Fatma and F.M. Salem (1999). Effect of organic manure and foliar application of some macro and micronutrients on wheat. Zagazig J. Agric. Res., 26(2): 445-456.

Devakumar, M. (1995). Influence of weed management and gypsum application on growth, yield and oil content of groundnut. Ph. D. Thesis, I.A.R.I., New Delhi, India.

El-Howeity, M.A. (2008). Diazotrophy and growth of beans (Phaseolus vulgaris) genotype inoculated with rhizobia and lactic acid bacteria. Minufiya J. Agric. Res., 33(5): 1283-1269.

El-Howeity, M.A.; A.A. Abdalla, Hanna, A. Abo-Kora and M.M. El-Shinnawi (2009). Response of faba bean to inoculation with Rhizobium leguminosarium and other Rhizobacteria under three nitrogen levels in newly reclaimed soil. J. Agric. Mansoura Univ., 34(6): 7259-7272.

El-Naggar, I.M.; A.A. Darwish and A.M. Hauna (1996). Response of cotton plant to application of some soil amendments and phosphorus fertilization. Menofiya $J$. Agric. Res., 21(3): 715-731.

El-Saadany, S.; Sh.M. Abd El-Rasoul; H.M. Hasan and A.A. Salem (2003). Effect of different sources of calcium and phosphorus on peanut plant grown on sandy soils. Annals of Agric. Sci. Moshtohor, 41(1): 331-338.

Fayoum J. Agric. Res. \& Dev., Vol.25, No.1, January, 2011 
El-Sawy, W.A.; G.A.A. Mekhemer and B.A.A. Kandil (2006). Comparative assessment of growth and yield responses of two peanut genotypes to inoculation with Bradyrhizobium conjugated with cyanobacteria or rhizobacteria. Minufia J. Agric. Res., 31(4): 1031-1049.

El-Shahawy, M.I. (2003). Effect of phosphor-gypsum, FYM and subsoiling on some salt affected soil properties and its productivity at North Delta. J. Agric. Sci. Mansoura Univ., 28(10): 7539-7546.

Fageria, N.K.; V.C. Baligar and C.A. Jones (1997). Growth and mineral nutrition of field crops. $2^{\text {nd }}$ Ed. Marcel Dekker Inc., New York, USA, 494 pp.

Gendy, E.N.; R.A. Derar and Kh. M. El-Aseel (1996). Response of soybean plants to gypsum and phosphate application. Minufiya J. Agric. Res., 21(2): 435-441.

Glick, B.R. (1995). The enhancement of plant growth by free living bacteria. Can. J. Microbial., 41: 109-117.

Hesse, P.R. (1971). Test Book of Soil Chemical Analysis. John Murray (Publisher) London, Greet Britain.

Husen, E. (2003). Screening of soil bacteria for plant growth promoting activities in vitro. Indonesian J. Agric. Sci., 4: 27-31.

Hussein Samira, M.A.; A.M. El-Melegy and M.A. Haikel (2000). Effect of nitrogen frequency, gypsum application, plant density and their interaction on growth and yield of peanut under drib irrigation system in North Sinai. J. Agric. Sci. Mansoura Univ., 25(5): 2427-2438.

Ismail, K.M. (2005). Yield and yield quality of peanut grown on sandy soils as affected by gypsum application. Egypt. J. Appl. Sci., 20(4B): 722-732.

James, F.L.; I.J. Davied; F.S. Jamal, W.Randg and P.D. Johnson (2005). Peanut response to inoculation and nitrogen fertilizer. American Society of Agronomy J., 97: 79-84.

Kenany, R.E.; A.A. Abdel-Magid; H.G. Abu El-Fotoh and A.M. Hamissa (2000). Effect of the addition of sulphur, phosphorus, potassium and some micronutrients on soybean productivity and phosphorus utilization. Proc. IAOPN $\mathrm{X}^{\text {th }}$ International Colloquium "Plant Nutrition for the Next Millennium: Nutrients, Quality and the Environment", April 8-13, 2000, Cairo, Egypt.

Lindsay, W.L. and W.A. Norvell (1978). Development of DTPA- micronutrients soil tests for zinc, iron, manganese and copper. Soil Sci. Am. J., 42: 421.

Lovenday, J. (1974). Method for Analysis of Irrigated Soils. CAG Fornham Royal Bucks, England.

Massoud, A.M. (2006). Effect of soil amendments and inoculation with rhizobium on the productivity of pea grown in heavy clay soil. Egypt J. of Appl. Sci., 21(7): 371391.

Massoud, A.M.; M.Y. Abou-Zeid and A.M. Bakry (2005). Response of pea plants grown on silty clay soil to micronutrients and rhizobium inoculation. Egypt. J. of Appl. Sci., 20(6): 329-346.

Mehasen, S.A.S. and M.A. El-Ghazoli (2003). Response of soybean plants to foliar application with iron and molybdenum and soil fertilization with rock-phosphate and phosphate dissolving bacteria. Minufiya J. Agric. Res., 28(1): 87-102.

Mekhemer, G.A.A. and A.A. Al-Kahal (2002). Enhancement of growth, nodulation and yield of bean plants by soil inoculation with Saccharomyces cerevisiae. Bull. Fac. Agric., Cairo Univ., 53: 489-502.

Fayoum J. Agric. Res. \& Dev., Vol.25, No.1, January, 2011 
Modaihsh, W.A. and A.L. Metwally (1989). Effect of elemental sulphur on chemical changes and nutrients availability in calcareous soils. Plant and Soil, 116: 95-101.

Mohamed, S.S.; M.A. negm and M.G. Rehan (1997). Gypsum amendment against soil alkalinity in relation to tomato plants. Change in agro-chemical properties and nutrients availability of the soil. J. Sci. Mansoura Univ., 105-112.

Morschner, H. (1998). Mineral Nutrition in Higher Plants. Academic Press, Harcount Brace Jovanovisch Publisher.

Morsy, M.A.; A.R. Abdallah and M.A. Kisshk (1982). Effect of soil amendments on the improvement of the newly reclaimed sandy calcareous soils of Minia Governorate. $1^{\text {st }}$ National Conference on the Problems of Land Degradation in Egypt, 2-3 February, Minia Univ. Egypt.

Nassar, K.E.M. (2005). Response of peanut crop to foliar application of some micronutrients under sandy soil conditions. Annal. Agric. Sci. Moshtohor, 43(4): 2003-2014.

Nassar, K.E.M. (2007). Response of faba bean and soybean to direct and residual impacts of sulphur at different levels of phosphorus and iron spraying under calcareous soil condition. Minufiya J. Agric. Res., 32(2): 537-552.

Nassar, K.E.; A.O. Osman; M.H. El-Kholy and Madiha, M. Badran (2002). Effect of seed coating with some micronutrients on faba bean (Vicia faba L.). Egypt. J. Soil Sci., 42(3): 363-381.

Nassar, K.E.M.; M.Y. Gebrail and K.M. Khalil (2000). Efficiency of phosphatedissolving bacteria (PDB) combined with different forms and rates of Pfertilization on the quality and quantity of faba bean (Vicia faba L.). Minufiya J. Agric. Res., 35(5): 1335-1349.

Osman, E.B.A. and M.M.M. Ahmed (2004). Response of some peanut varieties to rhizobium inoculation and some soil conditioners in sandy soil. Minufiya J. Agric. Res., 29(4): 1075-1089.

Othman, A. Sanaa; A.M.M. Shehata and I.M. El-Naggar (2005). Effect of rice straw compost and $\mathrm{N}$-fertilization on maize production and some soil physical properties. Minufiya J. Agric. Res., 30(6): 1853-1863.

Page, A.L.; R.H. Miller and D.K. Keeny (1982). Methods of Soil Analysis. Agron. No. 9, Part II: Chemical and Microbiological Properties, $2^{\text {nd }}$ Ed. ASA, Madison Wisconsin, USA.

Russell, E.W. (1961). Soil Conditions and Plant Growth. $8^{\text {th }}$ Ed. Longmans, London.

Saleh, S.H.; Nadia, M.A. Ghalab; G.A.A. Mekhemer and A.A. Abo El-Soud (2001). Response of peanut to inoculation with different strains of Bradyrhizobium Spp. As affected by fungicides. J. Agric. Sci. Mansoura Univ., 26: 5735-5748.

Shukla, U.C. and A.K. Mukhi (1979). Sodium, potassium and zinc relationship in corn. Agron. J., 71: 235-237.

Singh, A.L. (2001). Yield losses in groundnut due to micronutrient deficiencies in calcareous soils of India. In Plant Nutrition Food Security and Sustainability of Agro-ecosystems, 838-839. W.J. Horst et al., Kluwer Academic Publishers, Netherlands.

Snedecor, G.W. and G.W. Cochran (1982). Statistical Methods. $7^{\text {th }}$ Ed. Iowa State Univ. Press, Iowa, USA.

Fayoum J. Agric. Res. \& Dev., Vol.25, No.1, January, 2011 
Taksina, S. (1994). Field test on calcium and NPK fertilizer application for improving peanut yield in sandy soil. $12^{\text {th }}$ Thailand National Peanut Meeting. Thailand, Oct. 1994, 307:137-139.

Teuscher, H.; R. Adler and J.P. Seaton (1960). The Soil and its Fertility. Chapman and Hall, LTD. London.

Vincent, J.M. (1970). Manual for the Practical Study of Root-nodule Bacteria. IBP. Handbook No. 15, Blackwell Sci., Pub., Oxford.

$$
\begin{aligned}
& \text { إستجابة محصول الفول السودانى المنزرع فى أرض رملية حديثة الاستصلاح للتلقيح الحيوى } \\
& \text { مع إضافة الجبس والرش الرض بالحديد }
\end{aligned}
$$

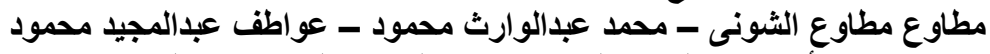

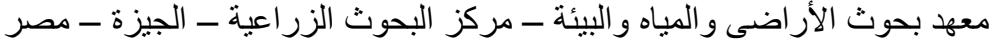

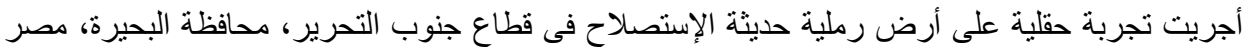

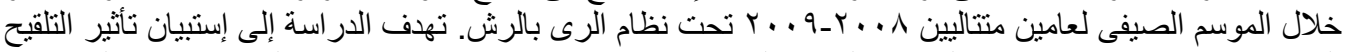

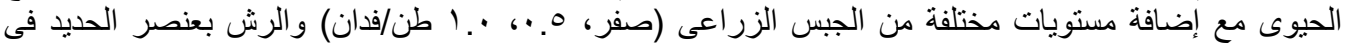

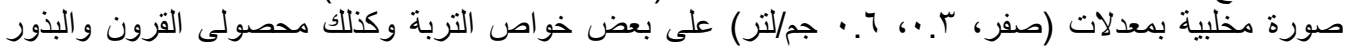

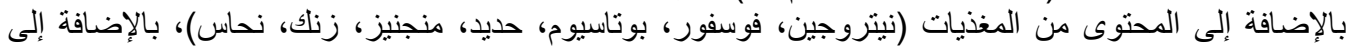

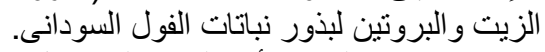

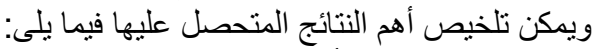

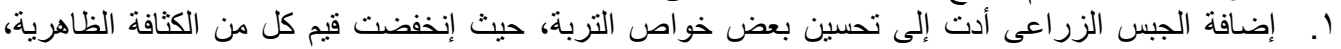
Soil pH

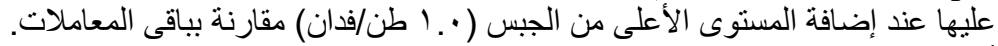

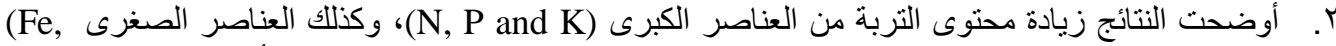
بزيادة معدل الإضافة من الجبس مع التلقيح بالريزوبيوم. وكانت أفضل القيم عند إضافة ( · (. طن جبس/فدان مع التلقيح بالريزوبيوم).

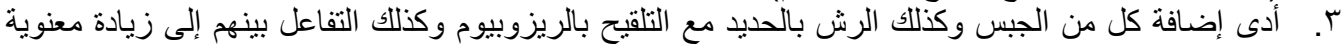

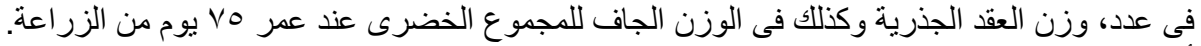

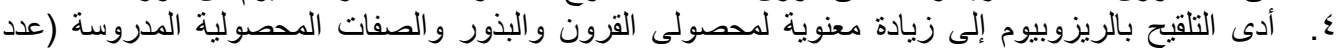

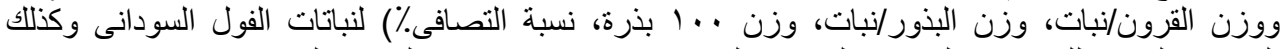

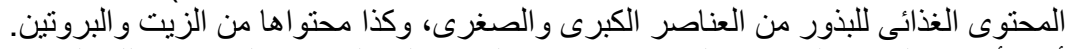

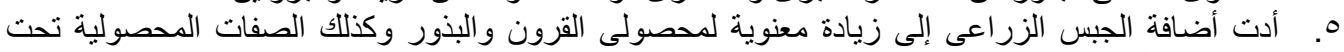

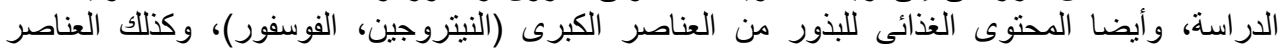

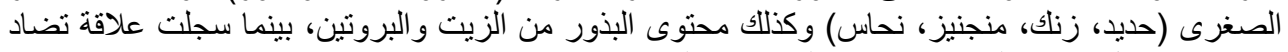

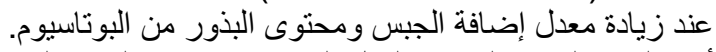

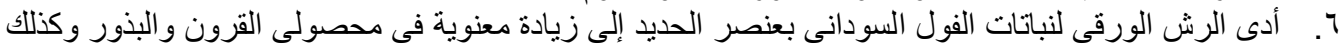

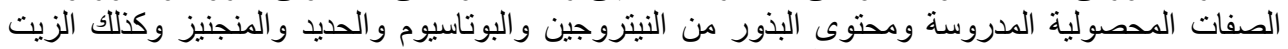

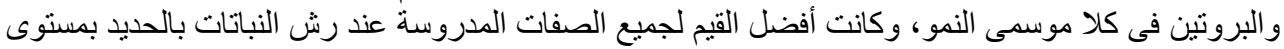

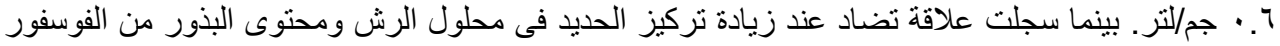
و الزنك و النحاس.

V. الجدير بالذكر أن التأثير المشترك للتلقيح بالريزوبيوم وإضافة الجبس و الرش بالحديد متحدة معاً أدى إلى زيادة

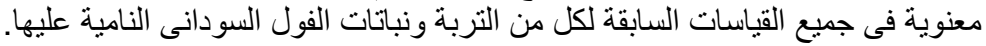

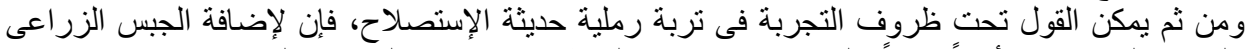

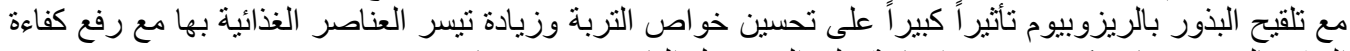

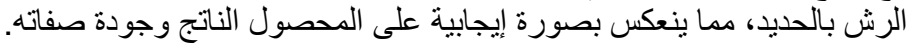

Fayoum J. Agric. Res. \& Dev., Vol.25, No.1, January, 2011 
Metawa M. El-Shouny, et al.

68

Table (10): $\mathrm{Fe}, \mathrm{Mn}, \mathrm{Zn}$ and $\mathrm{Cu}$ contents in peanut seeds as affected by rhizobium inoculation, gypsum and iron foliar spray applications (combined analysis of 2008 and 2009 seasons).

\begin{tabular}{|c|c|c|c|c|c|c|c|c|c|c|c|c|c|c|c|c|c|}
\hline \multirow{3}{*}{ 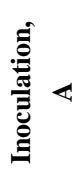 } & \multirow{3}{*}{ 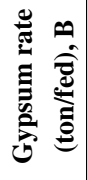 } & \multicolumn{4}{|c|}{$\mathrm{Fe}\left(\mathrm{mg} \mathrm{kg}^{-1}\right)$} & \multicolumn{4}{|c|}{$\operatorname{Mn}\left(\mathrm{mg} \mathrm{kg}^{-1}\right)$} & \multicolumn{4}{|c|}{$\mathrm{Zn}\left(\mathrm{mg} \mathrm{kg}^{-1}\right)$} & \multicolumn{4}{|c|}{$\mathrm{Cu}\left(\mathrm{mg} \mathrm{kg}^{-1}\right)$} \\
\hline & & \multicolumn{16}{|c|}{ Iron foliar spray $(\mathrm{g} / \mathrm{L}), \mathrm{C}$} \\
\hline & & 0.0 & 0.3 & 0.6 & Mean & 0.0 & 0.3 & 0.6 & Mean & 0.0 & 0.3 & 0.6 & Mean & 0.0 & 0.3 & 0.6 & Mean \\
\hline \multirow{4}{*}{ } & 0.0 & 203 & 262 & 293 & 253 & 28.3 & 29.0 & 31.2 & 29.5 & 32.3 & 38.7 & 34.7 & 35.2 & 4.80 & 4.50 & 4.10 & 4.50 \\
\hline & 0.5 & 247 & 317 & 342 & 302 & 30.9 & 30.6 & 34.2 & 31.9 & 45.6 & 45.3 & 40.6 & 43.8 & 4.90 & 4.90 & 4.50 & 4.80 \\
\hline & 1.0 & 293 & 335 & 377 & 335 & 32.3 & 33.5 & 33.2 & 33.0 & 59.5 & 52.4 & 45.6 & 52.5 & 6.00 & 5.80 & 5.20 & 5.70 \\
\hline & Mean & 247 & 304 & 337 & 297 & 30.5 & 31.0 & 32.9 & 31.4 & 45.8 & 45.5 & 40.3 & 43.8 & 5.23 & 5.06 & 4.60 & 5.00 \\
\hline \multirow{4}{*}{ @ } & 0.0 & 230 & 286 & 342 & 286 & 40.9 & 42.3 & 44.6 & 42.6 & 37.1 & 37.2 & 33.5 & 35.9 & 6.60 & 6.30 & 5.70 & 6.20 \\
\hline & 0.5 & 263 & 336 & 386 & 328 & 42.1 & 43.0 & 46.4 & 43.8 & 53.3 & 48.5 & 42.8 & 48.2 & 7.20 & 6.70 & 6.20 & 6.70 \\
\hline & 1.0 & 287 & 379 & 426 & 364 & 45.6 & 47.3 & 49.4 & 47.4 & 64.3 & 56.8 & 52.1 & 57.7 & 8.10 & 7.60 & 7.20 & 7.60 \\
\hline & Mean & 260 & 334 & 384 & 326 & 42.9 & 44.2 & 46.8 & 44.6 & 51.6 & 47.5 & 42.8 & 47.2 & 7.30 & 6.87 & 6.37 & 6.80 \\
\hline
\end{tabular}

Table (11): Fe, Mn, $\mathrm{Zn}$ and $\mathrm{Cu}$ uptake by peanut seeds as affected by rhizobium inoculation, gypsum and iron foliar spray applications (combined analysis of 2008 and 2009 seasons).

\begin{tabular}{|c|c|c|c|c|c|c|c|c|c|c|c|c|c|c|c|c|c|}
\hline \multirow{3}{*}{ 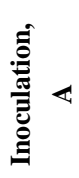 } & \multirow{3}{*}{ 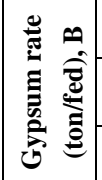 } & \multicolumn{4}{|c|}{$\mathrm{Fe}\left(\mathrm{g} \mathrm{fed}^{-1}\right)$} & \multicolumn{4}{|c|}{$\operatorname{Mn}\left(\mathrm{g} \mathrm{fed}^{-1}\right)$} & \multicolumn{4}{|c|}{$\operatorname{Zn}\left(\mathrm{g} \mathrm{fed}^{-1}\right)$} & \multicolumn{4}{|c|}{$\mathrm{Cu}\left(\mathrm{g} \mathrm{fed}^{-1}\right)$} \\
\hline & & \multicolumn{16}{|c|}{ Iron foliar spray $(\mathrm{g} / \mathrm{L}), \mathrm{C}$} \\
\hline & & 0.0 & 0.3 & 0.6 & Mean & 0.0 & 0.3 & 0.6 & Mean & 0.0 & 0.3 & 0.6 & Mean & 0.0 & 0.3 & 0.6 & Mean \\
\hline \multirow{4}{*}{ 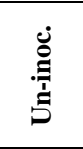 } & 0.0 & 147 & 208 & 248 & 201 & 20.5 & 22.9 & 26.4 & 23.2 & 23.4 & 30.6 & 29.4 & 27.8 & 3.48 & 3.56 & 3.47 & 3.50 \\
\hline & 0.5 & 208 & 287 & 330 & 275 & 25.9 & 27.6 & 33.0 & 28.8 & 38.3 & 40.9 & 39.2 & 39.5 & 4.12 & 4.42 & 4.34 & 4.29 \\
\hline & 1.0 & 270 & 335 & 408 & 337 & 29.7 & 33.4 & 38.0 & 33.7 & 54.7 & 52.3 & 49.2 & 52.1 & 5.52 & 5.79 & 5.62 & 5.64 \\
\hline & Mean & 208 & 276 & 329 & 271 & 25.4 & 28.0 & 32.5 & 28.6 & 38.8 & 41.3 & 39.3 & 39.8 & 4.37 & 4.59 & 4.47 & 4.47 \\
\hline \multirow{4}{*}{ 总 } & 0.0 & 209 & 278 & 362 & 283 & 37.2 & 41.1 & 47.2 & 41.8 & 33.7 & 36.1 & 35.4 & 35.1 & 6.00 & 6.12 & 6.03 & 6.05 \\
\hline & 0.5 & 274 & 412 & 476 & 387 & 43.8 & 49.7 & 57.2 & 50.2 & 55.4 & 53.8 & 52.8 & 54.0 & 7.49 & 7.75 & 7.60 & 7.61 \\
\hline & 1.0 & 333 & 490 & 576 & 466 & 52.8 & 61.1 & 67.2 & 60.4 & 74.5 & 73.4 & 70.9 & 72.9 & 9.39 & 9.82 & 9.79 & 9.67 \\
\hline & Mean & 272 & 393 & 471 & 379 & 44.6 & 50.6 & 57.2 & 50.8 & 54.5 & 54.4 & 53.0 & 54.0 & 7.93 & 7.90 & 7.81 & 7.77 \\
\hline \multirow{7}{*}{ 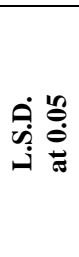 } & A & & \multirow{2}{*}{\multicolumn{4}{|c|}{$\begin{array}{l}1.82 \\
1.41\end{array}$}} & \multicolumn{4}{|c|}{0.98} & \multicolumn{4}{|c|}{0.22} \\
\hline & $\mathrm{B}$ & & & & & & & & & \multirow{2}{*}{\multicolumn{4}{|c|}{$\begin{array}{l}1.75 \\
0.78\end{array}$}} & \multicolumn{4}{|c|}{0.22} \\
\hline & $\mathrm{C}$ & \multicolumn{4}{|c|}{4.43} & \multicolumn{4}{|c|}{0.55} & & & & & \multicolumn{4}{|c|}{0.08} \\
\hline & $\mathrm{AxB}$ & \multicolumn{4}{|c|}{15.36} & \multicolumn{4}{|c|}{1.99} & \multicolumn{4}{|c|}{2.48} & \multirow{2}{*}{\multicolumn{4}{|c|}{0.31}} \\
\hline & $\mathrm{AxC}$ & \multicolumn{4}{|c|}{6.26} & \multicolumn{4}{|c|}{0.78} & \multicolumn{4}{|c|}{1.11} & \multirow{2}{*}{\multicolumn{4}{|c|}{$\begin{array}{l}0.12 \\
0.15\end{array}$}} \\
\hline & $\mathrm{BxC}$ & \multirow{2}{*}{\multicolumn{4}{|c|}{$\begin{array}{c}7.66 \\
10.84\end{array}$}} & \multicolumn{4}{|c|}{0.95} & \multicolumn{4}{|c|}{1.36} & & & & \\
\hline & $\mathrm{AxBxC}$ & & & 10.84 & & & & & & & & & & & & & \\
\hline
\end{tabular}

Fayoum J. Agric. Res. \& Dev., Vol.25, No.1, January, 2011 